\title{
$\mathrm{Cu}$ and $\mathrm{Pb}$ Accumulation and Removal From Aqueous Medium by Enydra Fluctuans DC. (Asteraceae) - A Medicinal Plant With Potential for Phytoremediation
}

\section{Sultana Parven}

Assam University

Aparajita De

Assam University

Abhik Gupta ( $\square$ abhik.eco@gmail.com )

Assam University https://orcid.org/0000-0001-6379-0271

\section{Research Article}

Keywords: Enydra fluctuans, $\mathrm{Cu}$ and $\mathrm{Pb}$ removal, phytoremediation, bioaccumulation, bioconcentration factor, translocation factor

Posted Date: August 3rd, 2021

DOl: https://doi.org/10.21203/rs.3.rs-634449/v1

License: (c) (1) This work is licensed under a Creative Commons Attribution 4.0 International License.

Read Full License 


\section{Abstract}

Enydra fluctuans DC. (Asteraceae) is an edible semi-aquatic floating or trailing herbaceous plant widely distributed in tropical Africa, South and South East Asia, and Australia. Its leaves, which are consumed as a vegetable, are also used in traditional medicine to treat several diseases. The efficacy of this plant in removal of copper and lead from aqueous medium was tested in the present study. Accumulation of both $\mathrm{Cu}$ and $\mathrm{Pb}$ was significantly higher in root than that in leaf and stem. Though all the bioconcentration factor (BCF) values were greater than unity, none of the translocation factor (TF) values was greater than unity, indicating that this plant could not be considered a hyperaccumulator of these metals. Nevertheless, $E$. fluctuans could remove $\mathrm{Cu}$ from aqueous medium at rates ranging from $98.8-99.7 \%$, with a mean reduction of $99.2 \%$ after $96 \mathrm{~h}$ exposure at various concentrations. The removal of $\mathrm{Pb}$ ranged from $97.1-99.1 \%$, with a mean reduction of $98.2 \%$. Thus, $E$. fluctuans showed high potential in removal of $\mathrm{Cu}$ and $\mathrm{Pb}$ from aqueous medium, and has the prospect of being used in phytoremediation of these metals.

\section{Introduction}

Various human activities such as industrialization and urbanization accompanied by rapid population growth have added different types of pollutants into the freshwater ecosystems (CPCB 2008). Among these pollutants, heavy metals are of worldwide concern because of their toxic properties, tendency to accumulate in biota, and persistent nature (Rai et al. 1981; Lokeshwari and Chandrappa 2007; Mishra and Tripathi 2008; Chang et al. 2009; Sood et al. 2012; Verma and Suthar 2015). Heavy metals and metalloids such as arsenic (As), cadmium (Cd), chromium (Cr), copper (Cu), mercury $(\mathrm{Hg})$, lead $(\mathrm{Pb})$, zinc (Zn) and others can cause deleterious effects even at very low concentrations (Sood et al. 2012).

Different sources such as smelters, tanneries, textile, fuel production, military activities, chemical industry, mining, application of fertilizer, urban sewage, waste incineration, and unsafe disposal of hazardous industrial wastes release various toxic heavy metals into the environment (Mishra and Tripathi 2008; Verma and Suthar 2015; Hargreaves et al. 2018; Ali et al. 2020). Some conventional techniques that are used for remediation of heavy metal pollutants include oxidation, chemical precipitation, adsorption, coagulation-flocculation, ion exchange, membrane filtration, ozonation, hydrogen peroxide-based methods, , photocatalytic degradation, reverse osmosis, electrodialysis and electrochemical methods. However, these are mostly metal specific, expensive, energy-intensive, and often have adverse effects on the environment (Mishra and Tripathi 2008; Olguin and Sánchez-Galván 2012; Lara et al. 2014; Rezaniaa et al. 2016). Under these circumstances, it is necessary to identify broad-spectrum, simple and costeffective technologies for removal of toxic metals (Zhang et al. 2020). The idea of using plants to cleanup pollutants from the environment was introduced in 1983, though this method was being applied for the last 300 years (Ali et al. 2020). These technologies are also named as green remediation, botanoremediation, vegetative remediation, and agro remediation (Sarwar et al. 2017; Kushwaha et al. 2018). Therefore, phytoremediation technologies to clean up environmental contaminants from water, soil and air using living plants (Raskin and Ensley 2000; Terry and Banuelos 2000; Maletić et al. 2019; Moya et al. 
2019) comprise viable, innovative, non-intrusive and cost-effective alternatives to other conventional methods (Singh et al. 1996; Miretzky et al. 2004; Putra et al. 2015). Plants that are used in the process of phytoremediation take up heavy metals through their roots and later transfer these contaminants to the above-ground parts of their body (Ashraf et al. 2018).

Aquatic macrophytes are of structural and functional significance in aquatic ecosystems because they provide stable habitats, and are a source of food and oxygen to the macroinvertebrate and fish fauna. They contribute to nutrient cycling, improve water quality by regulating oxygen balance and also play an important role in heavy metal accumulation (Srivastava et al. 2008; Dhote and Dixit 2009). Their high biomass yield, fast growth rate, high tolerance, ability to accumulate heavy metals, and direct exposure to contaminated water, facilitate their remediation ability, which enables them to act as natural water filtration systems (Sood et al. 2012). The roots, shoots, and leaves of aquatic macrophytes have the capacity to absorb heavy metals from aquatic environments, while their roots have the potential to sequester selected heavy metals (Mishra et al. 2009; Paiva et al. 2009; Muffarrege et al. 2010). Heavy metal uptake by aquatic plants involve three broad mechanisms: (i) accumulation, whereby plants concentrate and transport metals from water into plant body such as roots; (ii) binding of metals to cell walls of roots, thereby restricting their entry into the plant; and (iii) confining to the roots the metals that are still able to enter the plant, thus restricting their transport to shoots (Mishra and Tripathi 2008).

Various aquatic plants like duckweed (Lemna minor) (Mo et al. 1989), pennywort (Hydrocotyle umbellata) (Dierberg et al. 1987), water velvet (Azolla pinnata) (Jain et al. 1989), water hyacinth (Eichhornia crassipes) (Mishra and Tripathi 2008), water lettuce (Pistia stratiotes L.) (Putra et al. 2015), Ipomoea aquatica (Khumanleima Chanu and Gupta 2014; Bedabati Chanu and Gupta 2016; Haokip and Gupta 2020), and several other species have been reported to remove various heavy metals from solution. Enydra fluctuans DC. (Asteraceae), which is a floating or trailing macrophyte has been selected in the present study for testing its efficacy in removal of copper and lead from aqueous medium. This plant, which is commonly available in the study area of Barak Valley, South Assam, is also widely distributed in tropical Africa, South and South East Asia, and Australia. It is an edible, semi-aquatic herbaceous vegetable plant with serrate leaves (Rahman et al. 2002; Sannigrahi et al. 2011; Dua et al. 2015). The slightly bitter leaves are extensively used in traditional medicine to treat small-pox, inflammation and skin diseases (Kirtikar and Basu 2002). It is also used as an antibilious agent for treating liver disorders and neural diseases (Chopra et al. 2000; Kuri et al. 2014); anthelmintic and anti-inflammatory (Ali et al. 1972); analgesic (Rahman et al. 2002); and hypotensive (Kuri et al. 2014). Furthermore, it is packed with vitamins and other nutrients (Dua et al. 2015). The plant grows abundantly in rice fields, ditches, drains, natural channels and edges of fish ponds, where they propagate by fragmentation and often choke the water courses (Ali et al. 2013). However, its potential for removal of heavy metals from aqueous medium has not been assessed to any great extent, though it is known to have the ability to remove the metalloids arsenic and boron from water (Shaheen et al. 2006, 2007).

The two heavy metals copper and lead were selected for several reasons. Copper $\mathrm{Cu}$ ) is an essential micronutrient for the growth of plants and a constituent trace nutrient of the protein component of 
several enzymes, most of which are involved in catalyzing redox reactions, electron flow, etc. However, $\mathrm{Cu}$ can be toxic at high concentrations that are extremely harmful to both plants and animals (Devi and Prasad 1998; Wang and Dei 2001; Khumanleima Chanu and Gupta 2014). Due to direct exposure to its toxic effects, many aquatic plants are more sensitive to copper than their terrestrial counterparts (Fernandes and Henriques 1991). Cu is commonly used as a fungicide in tea plantations and different agricultural lands in the study area (Khumanleima Chanu and Gupta 2014). Lead at concentrations of more than $0.03 \mathrm{mg} / 100 \mathrm{gm}$ (FAO/WHO 2001) can cause blood diseases and affect nervous system, teeth and gum, liver, pancreas, and bones in humans (Khan 2015). Lead is dense, soft, durable, and corrosionresistant with a relatively low melting point, making it a major constituent of paint, ammunition, leaded glass, solder, storage batteries, etc. (Abadin et al. 2007). The principal consumption of lead (i.e., 80\% of the total use of lead) is for the lead-acid storage battery, and untreated wastewater containing lead used in recycling of batteries is released into the water bodies in the study area (Bedabati Chanu and Gupta 2016). In developing countries, there is a rapid increase in the demand for lead batteries due to an increase in the number of motorized vehicles, solar panels, telecommunication and computers (OK International 2021). A review of the available scientific literature reveals that the $\mathrm{Cu}$ and $\mathrm{Pb}$ accumulation and removal by $E$. fluctuans are not documented. Considering the above facts, the present paper is an attempt to critically evaluate the potential of this plant to accumulate $\mathrm{Cu}$ and $\mathrm{Pb}$ in its different tissues, and to remove these heavy metals from aqueous medium.

\section{Materials And Methods}

\section{Plant material and culture of plants}

Enydra fluctuans DC. was collected from water bodies of Irongmara area (latitude: $24.689^{\circ} \mathrm{N}$, longitude: $92.742^{\circ} \mathrm{E}$ ) in Cachar district, Assam, India. The plant material was brought to the laboratory in a plastic bag and washed with tap water. The plants were grown in hydroponic culture system till they developed new branches. These new branches were cut and grown in soil flooded with $50 \%$ modified Hoagland nutrient solution with its pH maintained at 5.8-6.2 (Göthberg et al. 2004; Bedabati Chanu and Gupta 2016). Hoagland nutrient medium comprised of $1 \mathrm{mM} \mathrm{MgSO}_{4} \cdot 7 \mathrm{H}_{2} \mathrm{O}, 2.5 \mathrm{mM} \mathrm{Ca}\left(\mathrm{NO}_{3}\right)_{2} \cdot 4 \mathrm{H}_{2} \mathrm{O}, 0.5 \mathrm{mM}$ $\mathrm{KH}_{2} \mathrm{PO}_{4}, 2.5 \mathrm{mM} \mathrm{KNO}_{3}, 23 \mu \mathrm{M} \mathrm{H}_{3} \mathrm{BO}_{3}, 0.39 \mu \mathrm{M} \mathrm{ZnSO}_{4} .7 \mathrm{H}_{2} \mathrm{O}, 4.58 \mu \mathrm{M} \mathrm{MnCl}_{2} \cdot 4 \mathrm{H}_{2} \mathrm{O}, 0.16 \mu \mathrm{M} \mathrm{CuSO}_{4} .5 \mathrm{H}_{2} \mathrm{O}$, $0.05 \mu \mathrm{M} \mathrm{Na}_{2} \mathrm{MoO}_{4} \cdot 2 \mathrm{H}_{2} \mathrm{O}$ and $50 \mu \mathrm{M}$ Fe-EDTA (Hoagland and Arnon 1950). To avoid Pb precipitation, $\mathrm{KH}_{2} \mathrm{PO}_{4}$ was not added to the nutrient solution (Qiao et al. 2013, Bedabati Chanu and Gupta 2016). The control plants were also cultured in $50 \%$ Hoagland nutrient medium without $\mathrm{KH}_{2} \mathrm{PO}_{4}$.

\section{Chemicals}

The metals used in the present study were copper as cupric chloride $\left(\mathrm{Cucl}_{2} \cdot 2 \mathrm{H}_{2} \mathrm{O}\right)$ and lead as lead nitrate $\left(\mathrm{Pb}\left(\mathrm{NO}_{3}\right)_{2}\right.$. The metals were added to the $50 \%$ Hoagland nutrient medium to obtain different graded concentrations for performing the tests. The nutrient solution without added $\mathrm{Cu}$ and $\mathrm{Pb}$ served as control. 


\section{Experimental Methods}

Fully grown healthy shoots of similar height (20-25 cm long) were cut from the same mother plant, washed with tap water and placed in $50 \%$ Hoagland nutrient media for 1 week (Temperature: $22-25^{\circ} \mathrm{C}$;

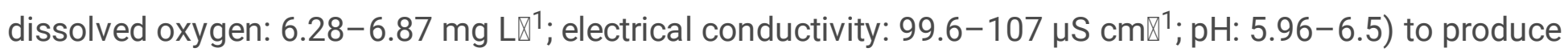
new roots. After the acclimatization period, plants of similar shoot height were exposed to $\mathrm{Cu}$ and $\mathrm{Pb}$ in two sets of experiments. Plants were exposed for $96 \mathrm{~h}$ to graded concentrations of $\mathrm{Cu}$ (nominal concentrations: $1.05,3.3,6.2$ and $11.2 \mathrm{mg} \mathrm{L} \otimes^{1}$; corresponding measured concentrations: $0.55,2.9,5.7$ and $10.2 \mathrm{mg} \mathrm{L} \otimes^{1}$ ) and $\mathrm{Pb}$ (nominal concentrations: 12.5, 22.0, 37.2 and $52.5 \mathrm{mg} \mathrm{L} \mathbb{\nabla}^{1}$; corresponding measured concentrations: $11.5,20.1,35.7$ and $50.2 \mathrm{mg} \mathrm{L \otimes}^{1}$ ) in $50 \%$ Hoagland medium contained in hydroponic microcosms consisting of $1000 \mathrm{ml}$ conical flasks. $\mathrm{Cu}$ and $\mathrm{Pb}$ concentrations in Indian rivers ranged from 0.003-314.93 and 0.010-374.58 $\mu \mathrm{g} \mathrm{L}^{-1}$, respectively, while $\mathrm{Cu}$ and $\mathrm{Pb}$ concentrations in rivers of the study area could reach up to 134.25 and $19.76 \mu \mathrm{g} \mathrm{L}^{-1}$, respectively (CWC 2014, 2018). Laboratory acclimatized plants without added $\mathrm{Cu}$ and $\mathrm{Pb}$ served as control in all the experiments. The plant parts were harvested after $3 \mathrm{~h}, 24 \mathrm{~h}, 48 \mathrm{~h}$ and $96 \mathrm{~h}$ of the experiment for determining uptake and accumulation of $\mathrm{Cu}$ and $\mathrm{Pb}$.

\section{Estimation of $\mathrm{Cu}$ and $\mathrm{Pb}$}

The $\mathrm{Cu}$ and $\mathrm{Pb}$ content in the plant samples were estimated using standard methods (Gupta 1996; Khumanleima Chanu and Gupta 2014). As soon as the experiments were completed, the leaf, stem and root were separated and cut into small pieces, and after drying to a constant weight at $60 \pm 2^{\circ} \mathrm{C}$, were ground and digested with concentrated $\mathrm{HNO}_{3}$. The residues were dissolved in deionized water and the concentrations of $\mathrm{Cu}$ and $\mathrm{Pb}$ were estimated in a graphite furnace atomic absorption spectrophotometer (model-Analytic Jena Vario-6) at the Sophisticated Analytical Instrument Facility (SAIF), North Eastern Hill University (NEHU), Shillong. $\mathrm{Cu}$ and $\mathrm{Pb}$ concentrations were also determined in samples of test medium collected from the microcosms at 0, 3, 24, 48 and $96 \mathrm{~h}$.

\section{Bioconcentration and Translocation Factor}

The ability of the plant to absorb $\mathrm{Cu}$ and $\mathrm{Pb}$ from an aqueous medium and its capacity to translocate them from the roots to different tissues of the plant are expressed by the Bioconcentration Factor (BCF) and the Translocation Factor (TF), respectively. BCF and TF were calculated by the following formulae:

\section{$\mathrm{BCF}=\frac{\text { Metal concentration in } \mu \mathrm{g} \mathrm{g}^{-1} \text { dry weight }(\mathrm{dw}) \text { plant tissue }}{\text { Initial concentration of metal in the medium }\left(\mathrm{mg} \mathrm{L}^{-1}\right)}$}

(Ivanciuc et al. 2006; Ahmad et al. 2011), and

$$
\mathrm{TF}=\frac{\text { Metal concentration in stem or leaf }\left(\mu \mathrm{g} \mathrm{g}^{-1} \mathrm{dw}\right)}{\text { Metal concentration in } \operatorname{root}\left(\mu \mathrm{g} \mathrm{g}^{-1} \mathrm{dw}\right)}
$$


(Ahmad et al. 2011).

\section{Statistical analysis}

The data sets were subjected to One-way ANOVA to find the statistical significance of differences among them, with multiple comparisons made by Tukey tests. SPSS 20 software was used for performing all tests and wherever necessary log transformation of data was also done.

\section{Results And Discussion}

\section{Accumulation of copper and lead in different tissues of E. fluctuans}

The accumulation of $\mathrm{Cu}$ in leaf, stem and root of E. fluctuans after 3, 24, 48 and $96 \mathrm{~h}$ of exposure to graded concentrations of $\mathrm{Cu}$ are shown in Table 1. Cu was not detected in the tissues of the control plants. One-way ANOVA with multiple comparisons by Tukey tests revealed that there were significant differences $(p<0.001)$ in $\mathrm{Cu}$ accumulation among the three tissues of $\mathrm{Cu}$-exposed plants at all concentrations and hours of exposure, in the order root $>$ leaf $>$ stem. There was a consistent increase in accumulation of $\mathrm{Cu}$ in the root with increasing concentration and duration of exposure, although this trend was not evident in the leaf and stem. The highest Cu concentration of $980.90 \pm 20.81 \mu \mathrm{g} \mathrm{g}^{-1} \mathrm{dry}$ weight (DW) was observed in the root of plants exposed to $10.2 \mathrm{mg} \mathrm{Cu} \mathrm{L}^{-1}$ at $96 \mathrm{~h}$. On the other hand, the lowest accumulation was $41.04 \mathrm{Cu} \mu \mathrm{g} \mathrm{g}^{-1} \mathrm{DW}$ in the stem exposed to $0.55 \mathrm{mg} \mathrm{Cu} \mathrm{L}^{-1}$ at $3 \mathrm{~h}$. The highest $\mathrm{Cu}$ concentrations recorded in the leaf and stem were $129.01 \pm 0.10$ and $168.55 \pm 0.39 \mathrm{\mu g} \mathrm{g}^{-1} \mathrm{DW}$, respectively, when exposed to $10.2 \mathrm{mg} \mathrm{Cu} \mathrm{L}^{-1}$ at 24 and $3 \mathrm{~h}$, respectively. 
Table 1

Accumulation of $\mathrm{Cu}$ in different tissues of E. fluctuans at different $\mathrm{Cu}$ concentrations

\begin{tabular}{|c|c|c|c|c|c|}
\hline \multirow[t]{2}{*}{$\mathrm{Cu}$ in $\mathrm{mg} \mathrm{L}^{-1}$} & \multirow{2}{*}{$\begin{array}{l}\text { Plant } \\
\text { tissue }\end{array}$} & \multicolumn{4}{|c|}{ Cu accumulation ( $\left.\mu \mathrm{g} \mathrm{g}^{-1} \mathrm{DW}\right)$} \\
\hline & & $3 \mathrm{~h}$ & $24 \mathrm{~h}$ & $48 \mathrm{~h}$ & $96 \mathrm{~h}$ \\
\hline Control & leaf & ND & ND & ND & ND \\
\hline \multirow[t]{3}{*}{0.55} & & $52.78 \pm 2.04^{a}$ & $108.70 \pm 1.41^{\mathrm{a}}$ & $83.00 \pm 2.52^{\mathrm{a}}$ & $146.34 \pm 1.00^{\mathrm{a}}$ \\
\hline & stem & $41.04 \pm 1.13^{b}$ & $90.77 \pm 1.01^{b}$ & $45.95 \pm 0.86^{b}$ & $72.63 \pm 1.17^{b}$ \\
\hline & root & $90.98 \pm 0.76^{c}$ & $151.26 \pm 0.36^{c}$ & $191.69 \pm 0.65^{c}$ & $232.00 \pm 0.92^{c}$ \\
\hline \multirow[t]{3}{*}{2.9} & leaf & $72.93 \pm 0.11^{a}$ & $125.84 \pm 0.70^{\mathrm{a}}$ & $95.19 \pm 0.88^{a}$ & $151.56 \pm 0.22^{\mathrm{a}}$ \\
\hline & stem & $52.65 \pm 0.69^{b}$ & $92.58 \pm \pm 0.42^{b}$ & $76.43 \pm 1.43^{b}$ & $73.12 \pm 1.07^{b}$ \\
\hline & root & $189.44 \pm 0.44^{\mathrm{c}}$ & $202.23 \pm 0.31^{c}$ & $255.25 \pm 2.57^{c}$ & $375.69 \pm 0.42^{c}$ \\
\hline \multirow[t]{3}{*}{5.7} & leaf & $84.82 \pm 0.18^{a}$ & $129.57 \pm 0.36^{a}$ & $110.77 \pm 3.19^{a}$ & $115.77 \pm 0.33^{\mathrm{a}}$ \\
\hline & stem & $57.27 \pm 0.77^{b}$ & $95.59 \pm 0.44^{b}$ & $92.72 \pm 0.54^{b}$ & $75.31 \pm 0.72^{b}$ \\
\hline & root & $251.41 \pm 0.31^{c}$ & $238.43 \pm 0.34^{c}$ & $325.77 \pm 0.32^{c}$ & $450.98 \pm 0.86^{c}$ \\
\hline \multirow[t]{3}{*}{10.2} & leaf & $168.55 \pm 0.39^{a}$ & $131.51 \pm 0.45^{\mathrm{a}}$ & $107.46 \pm 2.26^{a}$ & $164.84 \pm 0.68^{a}$ \\
\hline & stem & $81.87 \pm 0.50^{b}$ & $129.01 \pm 0.10^{\mathrm{b}}$ & $95.67 \pm 1.12^{b}$ & $115.47 \pm 0.73^{b}$ \\
\hline & root & $501.95 \pm 0.63^{c}$ & $606.08 \pm 4.65^{c}$ & $965.48 \pm 3.48^{c}$ & $980.90 \pm 20.81^{c}$ \\
\hline
\end{tabular}

Though copper acts as an essential nutrient by playing a prominent role in enhancing photosynthesis, and promoting development, metabolism and growth of plants, it can be highly toxic beyond certain threshold concentrations (Li and Xiong 2004). Copper affects several biochemical and physiological mechanisms in plants, inhibits growth, and imparts toxic effects due to accumulation in the tissues (Mishra and Tripathi 2008). Cu accumulation was highest in the roots due to its existence as cations i.e., $\mathrm{Cu}^{2+}$ and $\mathrm{Cu}^{+}$(Krupanidhi et al. 2008) which got attached to negative charges present in the structure of cell wall in the roots (Göthberg 2008). Khumanleima Chanu and Gupta (2014) also found that roots of Ipomoea aquatica accumulated higher amount of copper than the apical parts of the plant.

In the case of $\mathrm{Pb}$ accumulation, a pattern similar to that observed for $\mathrm{Cu}$ could be observed (Table 2). $\mathrm{Pb}$ was not detected in the control plants, and its accumulation was highest in root, followed by that in leaf 
and stem. One-way ANOVA with multiple comparisons by Tukey tests revealed that there were significant differences $(p<0.001)$ in $\mathrm{Pb}$ accumulation among the tissues at all concentrations and hours of exposure, in the order root > leaf > stem. The highest $\mathrm{Pb}$ accumulation of $1093.60 \pm 4.08 \mathrm{\mu g} \mathrm{g}^{-1} \mathrm{DW}$ was found in the root after $96 \mathrm{~h}$ exposure to $50.2 \mathrm{mg} \mathrm{Pb} \mathrm{L}^{-1}$, while the lowest of $70.40 \pm 0.74 \mathrm{\mu g} \mathrm{g}^{-1} \mathrm{DW}$ was found in the stem after $3 \mathrm{~h}$ exposure to $50.2 \mathrm{mg} \mathrm{Pb} \mathrm{L}^{-1}$. The $\mathrm{Pb}$ concentrations consistently increased with increasing exposure concentration and length of exposure time in root, though this pattern was not clear in leaf and stem. The highest $\mathrm{Pb}$ concentrations in leaf were $194.05 \pm 1.82 \mathrm{\mu g} \mathrm{g}^{-1} \mathrm{DW}$ recorded at $24 \mathrm{~h}$ exposure to $50.2 \mathrm{mg} \mathrm{Pb} \mathrm{L}^{-1}$, while those in stem were $114.36 \pm 0.36 \mu \mathrm{g} \mathrm{g}^{-1} \mathrm{DW}$ at $96 \mathrm{~h}$ exposure to $20.1 \mathrm{mg} \mathrm{Pb} \mathrm{L}^{-1}$.

Table 2

Accumulation of $\mathrm{Pb}$ in different tissues of $E$. fluctuans at different $\mathrm{Pb}$ concentrations

\begin{tabular}{|c|c|c|c|c|c|}
\hline \multirow[t]{2}{*}{$\mathrm{Pb}$ in $\mathrm{mg} \mathrm{L}^{-1}$} & \multirow{2}{*}{$\begin{array}{l}\text { Plant } \\
\text { tissue }\end{array}$} & \multicolumn{4}{|c|}{$\mathrm{Pb}$ accumulation $\left(\mu \mathrm{g} \mathrm{g}^{-1} \mathrm{DW}\right)$} \\
\hline & & $3 h$ & $24 \mathrm{~h}$ & $48 \mathrm{~h}$ & $96 \mathrm{~h}$ \\
\hline Control & leaf & ND & ND & ND & ND \\
\hline \multirow[t]{3}{*}{11.5} & & $93.21 \pm 1.18^{\mathrm{a}}$ & $102.31 \pm 1.51^{a}$ & $96.87 \pm 0.73^{a}$ & $108.13 \pm 0.91^{\mathrm{a}}$ \\
\hline & stem & $74.76 \pm 3.33^{b}$ & $71.18 \pm 0.21^{b}$ & $90.98 \pm 0.49^{b}$ & $94.96 \pm 0.72^{b}$ \\
\hline & root & $257.36 \pm 0.58^{c}$ & $247.72 \pm 0.79^{c}$ & $328.07 \pm 0.99^{c}$ & $466.75 \pm 0.77^{c}$ \\
\hline \multirow[t]{3}{*}{20.1} & leaf & $107.51 \pm 0.61^{a}$ & $111.84 \pm 0.96^{a}$ & $124.50 \pm 1.33^{a}$ & $138.83 \pm 0.32^{\mathrm{a}}$ \\
\hline & stem & $78.47 \pm 0.40^{b}$ & $83.73 \pm 0.97^{b}$ & $92.08 \pm 1.36^{b}$ & $114.36 \pm 0.36^{b}$ \\
\hline & root & $299.31 \pm 0.67^{c}$ & $421.02 \pm 0.13^{c}$ & $505.23 \pm 0.40^{c}$ & $544.05 \pm 1.04^{c}$ \\
\hline \multirow[t]{3}{*}{35.7} & leaf & $122.28 \pm \pm 0.89^{a}$ & $113.34 \pm 0.63^{a}$ & $132.42 \pm 0.61^{a}$ & $143.98 \pm 0.19^{a}$ \\
\hline & stem & $92.17 \pm 1.43^{b}$ & $88.82 \pm 0.71^{b}$ & $99.64 \pm 0.44^{b}$ & $105.38 \pm 0.34^{b}$ \\
\hline & root & $325.95 \pm 1.20^{c}$ & $474.21 \pm 0.19^{c}$ & $653.92 \pm 0.89^{c}$ & $944.25 \pm 2.47^{c}$ \\
\hline \multirow[t]{3}{*}{50.2} & leaf & $139.11 \pm 1.03^{\mathrm{a}}$ & $194.05 \pm 1.82^{a}$ & $189.20 \pm 0.21^{\mathrm{a}}$ & $168.83 \pm 1.10^{\mathrm{a}}$ \\
\hline & stem & $70.40 \pm 0.74^{b}$ & $104.74 \pm 0.39^{b}$ & $111.64 \pm 0.60^{b}$ & $113.91 \pm 0.79^{b}$ \\
\hline & root & $587.72 \pm 3.09^{c}$ & $774.02 \pm 2.58^{c}$ & $877.13 \pm 4.47^{c}$ & $1093.60 \pm 4.08^{c}$ \\
\hline
\end{tabular}


The significantly higher accumulation of $\mathrm{Cu}$ and $\mathrm{Pb}$ in root than that in leaf and stem at all exposure concentrations could be related to the plant's strategy to cope with the toxicity of heavy metals by immobilizing them in the root cell vacuoles as shown in the case of $\mathrm{Cr}$ (Shankar et al. 2005b). The study also revealed that the transportation of lead from the root to the upper portion of the plant was restricted due to the high capacity of $\mathrm{Pb}$ retention in the root tissues (Bedabati Chanu and Gupta 2016). Other studies also reported the preferential accumulation of $\mathrm{Pb}$ and other heavy metals in the root of many different species of macrophytes (Lytle et al. 1998; Pulford et al. 2001; Deng et al. 2004).

\section{Bioconcentration factor (BCF) and translocation factor (TF) of $\mathrm{Cu}$ and $\mathrm{Pb}$ in different tissues of $\mathrm{E}$. fluctuans}

All BCF values of $\mathrm{Cu}$ and $\mathrm{Pb}$ in different tissues of E. fluctuans at exposure periods of 3, 24, 48 and $96 \mathrm{~h}$ were $>1.0$, with higher values recorded in root followed by those in leaf and the lowest in stem. The BCF values, which were higher for $\mathrm{Cu}$ than for $\mathrm{Pb}$, mostly recorded an increase with time of exposure, though this pattern was less evident in the case of $\mathrm{Pb}$ (Supplementary Tables S1 and S3). On the other hand, the $\mathrm{BCF}$ values for $\mathrm{Cu}$ in all the three tissues at all hours of exposure mostly declined with increasing $\mathrm{Cu}$ concentrations, though the decline was less pronounced in the case of $\mathrm{Pb}$. Thus, $E$. fluctuans was more efficient as a $\mathrm{Cu}$ accumulator at lower concentrations of the metal, though the BCF values remained as high as $>90$ at $10.2 \mathrm{mg} \mathrm{Cu} \mathrm{L}^{-1}$. The BCF values ranged from 8.03 in stem $-421.82 \pm 1.68$ in root for $\mathrm{Cu}$; and $1.40 \pm 0.01$ in stem $-40.59 \pm 0.07$ in root for $\mathrm{Pb}$. Bioconcentration Factor is the ability of the plant to absorb metals into their body parts from an aqueous medium (Maldonado-Magaña et al. 2011). Higher values of BCF imply the ability of the plant to accumulate metals at higher levels (Bedabati Chanu and Gupta 2016). The extremely high BCF values for $\mathrm{Cu}(>100)$ in E. fluctuans are similar to that found in many hyperaccumulators (Sun et al. 2009), though the low TF values rule out its inclusion in the category of hyperaccumulators. TF values for both $\mathrm{Cu}$ and $\mathrm{Pb}$ were all < 1 (Supplementary Tables $\mathrm{S} 2$ and S4), indicating that both these metals taken up by the plant remained confined mostly to the roots (Juang et al. 2011).

\section{Heavy metal removal by Enydra fluctuans from water}

The removal of Cu from aqueous medium by E. fluctuans (Table 3) revealed that the final reduction after $96 \mathrm{~h}$ exposure at various concentrations ranged from $98.8-99.7 \%$, with a mean reduction of $99.2 \%$. The removal of $\mathrm{Pb}$ ranged from $97.1-99.1 \%$, with a mean reduction of $98.2 \%$ (Table 4). These findings suggest that though not a hyperaccumulator, E. fluctuans shows high potential for removal of $\mathrm{Cu}$ and $\mathrm{Pb}$ from aqueous medium which may be aided by their higher biomass, rapid growth, and capability of metal absorption from aqueous medium as was also observed in several other species of macrophytes (Mant et al. 2007; Mishra and Tripathi 2008). Putra et al. (2015) reported that water lettuce (Pistia stratiotes Linn.) could remove 99\% of $\mathrm{Pb}$ from an aqueous medium. 
Table 3

Cu concentrations in water samples at different hours of treatment with

E. fluctuans. Percent reductions of $\mathrm{Cu}$ are given in parentheses

\begin{tabular}{|lllll|}
\hline \multicolumn{5}{|c|}{ Cu concentrations $\mathrm{mg} \mathrm{L}^{-1}$ (\% reduction) } \\
\hline 0 hour & 3 hour & 24 hour & 48 hour & 96 hour \\
$0.55(0)$ & $0.42(23.6)$ & $0.02(96.4)$ & $0.009(98.4)$ & $0.005(99.1)$ \\
$2.9(0)$ & $2.2(24.1)$ & $0.233(92.0)$ & $0.011(99.6)$ & $0.009(99.7)$ \\
$5.7(0)$ & $5.1(10.5)$ & $0.823(85.6)$ & $0.096(98.3)$ & $0.055(99.0)$ \\
$10.2(0)$ & $9.6(5.9)$ & $1.52(85.1)$ & $0.201(98.0)$ & $0.121(98.8)$ \\
\hline
\end{tabular}

Table 4

$\mathrm{Pb}$ concentrations in water samples at different hours of treatment with E. fluctuans. Percent reductions of $\mathrm{Pb}$ are given in parentheses

\begin{tabular}{|lllll|}
\hline \multicolumn{5}{|c|}{$\mathrm{Pb}$ concentrations $\mathrm{mg} \mathrm{L}^{-1}$ (\% reduction) } \\
\hline 0 hour & 3 hour & 24 hour & 48 hour & 96 hour \\
\hline $11.5(0)$ & $9.2(20.0)$ & $5.8(49.6)$ & $0.55(95.2)$ & $0.33(97.1)$ \\
$20.1(0)$ & $18.7(7.0)$ & $11.6(42.3)$ & $0.565(97.2)$ & $0.392(98.1)$ \\
$35.7(0)$ & $29.9(16.3)$ & $15.7(56.0)$ & $0.852(97.6)$ & $0.572(98.4)$ \\
$50.2(0)$ & $47.5(5.4)$ & $27.9(44.4)$ & $0.92(98.2)$ & $0.46(99.1)$ \\
\hline
\end{tabular}

\section{Conclusions}

Due to its widespread occurrence in several parts of the world, the plant $E$. fluctuans is a suitable candidate for its possible utility in phytoremediation of metal-contaminated water as well as in the assessment and biomonitoring of metals and metalloids in freshwater habitats. The present investigation revealed that the plant could survive in fairly high $\mathrm{Cu}$ and $\mathrm{Pb}$ (up to $10.2 \mathrm{Cu}$ and $50.2 \mathrm{~Pb} \mathrm{mg}$ $\mathrm{L}^{-1}$ ) contaminated medium. It could also strongly accumulate these metals, especially in the roots, with $\mathrm{BCF}$ values for $\mathrm{Cu}$ reaching $>400$ and those for $\mathrm{Pb}>40$. Further, the plant could remove $\mathrm{Cu}$ and $\mathrm{Pb}$ from aqueous medium at an average rate of 99.2 and 98.2 percent, respectively, after a relatively short exposure time of $96 \mathrm{~h}$. These characteristic features, coupled with its ability to asexually propagate by fragmentation, makes it a plant worth exploring for its potential for phytoremediation of water contaminated with toxic metals and metalloids.

\section{Declarations}

Acknowledgements We thank Sophisticated Analytical Instrument Facility(SAIF), North Eastern Hill University, Shillong-793022, India and Tripura State Pollution Control Board, Agartala, Tripura-799006, for 
the estimation of copper and lead. We are also grateful to e-library facility by DELCON located at Bioinformatics Centre, Assam University, Silchar, India.

Authors' contributions Sultana Parven carried out the experimental work, statistical analysis, prepared the first draft and revisions of draft. Abhik Gupta and Aparajita De designed the experiment, helped in the analysis of statistics, developed the first draft and finalized.

Funding This work was supported financially by University Grant Commission, New Delhi, India by providing Non-Net Fellowship to SP.

Data availability The datasets used and/or analyzed during the current study are available from the corresponding author on reasonable request.

\section{Compliance with ethical standards}

Ethics approval and consent to participate Not applicable

Consent for publication Not applicable

Competing interests The authors declare that they have no competing interests.

\section{References}

1. Abadin H, Ashizawa A, Stevens YW, Llados F, Diamond G, Sage G, Citra M, Quinones A, Bosch SJ, Swarts SG (2007) Toxicological profile for Lead. Atlanta (GA). Agency for Toxic Substances and Disease Registry. http://www.ncbi.nlm.nih.gov/books/NBK158769/. downloaded on 12/01/2020

2. Ahmad A, Ghufran R, Zularisam AW (2011) Phytosequestration of metals in selected plants growing on a contaminated Okhla industrial area, Okhla, New Delhi, India. Water Air Soil Pollut 217(1):255266. https://doi.org/10.1007/s11270-010-0584-9

3. Ali E, Ghosh DP, Pakrashi SC (1972) Studies on Indian medicinal plants- xxviii sesquiterpene lactones of Enhydra fluctuans Lour. structures of enhydrin, fluctuanin and fluctuadin. Tetrahedron 28(2):2285-2298. https://doi.org/10.1016/S0040-4020(01)93572-0

4. Ali RM, Billah MM, Hassan MM, Dewan SMR, Al-Emran M (2013) Enhydra fluctuans Lour:: A Review. Res J Pharm Technol 6(9):927-929

5. Ali S, Abbas Z, Rizwan M, Zaheer IE, Yavas I, Ünay A, Abdel-DAIM M, Bin- Jumah M, Hasanuzzaman $M$, Kalderis $D$ (2020) Application of floating aquatic plants in phytoremediation of heavy metals polluted water: A Review. Sustainability 12(5):1927. https://doi.org/10.3390/su12051927

6. Ashraf S, Afzal M, Naveed M, Shahid M, Zahir ZA (2018) Endophytic bacteria enhance remediation of tannery effluent in constructed wetlands vegetated with Leptochloa fusca. Int J Phytoremediation 20(2):121-128. https://doi.org/10.1080/15226514.2017.1337072 
7. Bedabati Chanu L, Gupta A (2016) Phytoremediation of lead using Ipomoea aquatica Frosk. in hydroponic solution. Chemosphere 156:407-411. https://doi.org/10.1016/j.chemosphere.2016.05.001

8. Central Pollution Control Board (2008) Status of water quality in India 2007. CPCB, New Delhi

9. Chang JS, Yoon IH, Kim KW (2009) Heavy metal and arsenic accumulating fern species as potential ecological indicators in As-contaminated abandoned mines. Ecol Indic 9(6):1275-1279. https://doi.org/10.1016/j.ecolind.2009.03.011

10. Cheng S (2003) Heavy metals in plants and phytoremediation. Environ Sci Pollut Res 10(5):335340. http://dx.doi.orq/10.1065/espr2002.11.141.3

11. Chopra RN, Chopra SL, Chopra IC (2000) Glossary of Indian Medicinal Plants. New Delhi, NISC (CSIR), p 107

12. CWC (Central Water Commission) (2014) Status of Trace and Toxic Metals in Indian Rivers. River Data Directorate, Planning and Development Organization, New Delhi 110066. Ministry of Water Resources, Government of India

13. CWC (Central Water Commission) (2018) Status of Trace and Toxic Metals in Indian Rivers. River Data Compilation - 2 Directorate, Planning and Development Organization, New Delhi 110066. Ministry of Water Resources, Government of India

14. Deng H, Ye ZH, Wong MH (2004) Accumulation of lead, zinc, copper and cadmium by 12 wetland plants species thriving in metal contaminated sites in China. Environ Pollut 132(1):29-40. https://doi.org/10.1016/j.envpol.2004.03.030

15. Devi SR, Prasad MNV (1998) Copper toxicity in Ceratophyllum demersum L. (Coontail), a free floating macrophyte: response of antioxidant enzyme and antioxidants. Plant Sci 138(2):157-165. https://doi.org/10.1016/S0168-9452(98)00161-7

16. Dhote S, Dixit S (2009) Water quality improvement through macrophytes- a review. Environ Monit Assess 152:149-153. https://doi.org/10.1007/s10661-008-0303-9

17. Dierberg FE, Debusk TA, Goulet NA (1987) Jr. In: Reddy KR, Smith WH (eds) aquatic plants for water treatment and Resource Recovery. Magnolia Publishing Inc., Orlando, pp 497-504

18. Dua TK, Dewanjee S, Khanra R, Bhattacharya N, Bhaskar B, Zia-ul-Haq M, De Feo V (2015) The effects of two common edible herbs Ipomoea aquatica and Enhydra fluctuans on cadmium induced pathophysiology: a focus on oxidative defence and anti-apoptotic mechanism. J Transl Med 13:145. https://doi.org/10.1186/s12967-015-0598-6

19. FAO/WHO (2001) Food additives and contaminants. Joint Codex Alimentarius Commission

20. Fernandes JC, Henriques FS (1991) Biochemical, physiological, and structural effects of excess copper in plants. Bot Rev 57:246-273. https://doi.org/10.1007/BF02858564

21. Göthberg A, Greger M, Holm K, Bengtsson B-E (2004) Influence of nutrient levels on uptake and effects of mercury, cadmium, lead in Water spinach. J Environ Qual 33:1247-1255 
22. Göthberg A (2008) Metal fate and sensitivity in the aquatic tropical vegetable Ipomoea aquatica. Dissertation, Stockholm University

23. Gowd SS, Reddy MR, Govil PK (2010) Assessment of heavy metal contamination in soils at Jajmau (Kanpur) and Unnao industrial areas of the Ganga Plain, Uttar Pradesh, India. J Hazard Mater 174(13):113-121. https://doi.org/10.1016/j.jhazmat.2009.09.024

24. Gupta A (1996) Heavy metals in water, periphytonic algae, detritus and insects from two streams in Shillong, Northeastern India. Environ Monit Assess 40:215-223. https://doi.org/10.1007/BF00398867

25. Gupta M, Chandra P (1998) Bioaccumulation and toxicity of mercury in rooted submerged macrophyte Vallisneria spiralis. Environ Pollut 103(2-3):327-332. https://doi.org/10.1016/S02697491(98)00102-X

26. Haokip N, Gupta A (2020) Phytoremediation of chromium and manganese by Ipomoea aquatica Forssk. from aqueous medium containing chromium-manganese mixtures in microcosms and mesocosms. Water Environ J. https://doi.org/10.1111/wej.12676

27. Hargreaves AJ, Constantino C, Dotro G, Cartmell E, Campo P (2018) Fate and removal of metals in municipal wastewater treatment: A review. Environ Technol Rev 7(1):1-18. https://doi.org/10.1080/21622515.2017.1423398

28. Hoagland DR, Arnon DI (1950) The water-culture method for growing plants without soil. California Agricultural Experiment Station Circular 347:1-32

29. Ivanciuc T, Ivanciuc 0 , Klein DJ (2006) Modelling the bioconcentration factors and bioaccumulation factors of polychlorinated biphenyls with posetic quantitative super- structure/activity relationships (QSSAR). Mol Divers 10:133-145

30. Jain SK, Vasudevan P, Jha NK (1989) Removal of some heavy metals from polluted water by aquatic plants: Studies on duckweed and water velvet. Biol Wastes 28(2):115-126. https://doi.org/10.1016/0269-7483(89)90075-X

31. Juang KW, Lai HY, Chen BC (2011) Coupling bioaccumulation to predict copper removal by switchgrass grown hydroponically. Ecotoxicology 20:827-835. https://doi.org/10.1007/s10646-0110635-z

32. Khan MMRL, Satter MA, Jabin SA, Abedin N, Islam MF, Lisa LA, Paul DK (2015) Mineral and heavy metal contents of some vegetable available in local market of Dhaka city in Bangladesh. J Environ Sci Toxicol Food Technol 9(5):01-06. https://doi.org/10.9790/2402-09510106

33. Khumanleima Chanu H, Gupta A (2014) Necrosis as an adaptive response to copper toxicity in Ipomoea aquatica Forsk. and its possible application in phytoremediation. Acta Physiol Plant 36:3275-3281. https://doi.org/10.1007/s11738-014-1693-7

34. Kirtikar KR, Basu BD (2002) Indian Medicinal Plants. Sri Satguru Publications, Delhi. Vol. VIII, 1360

35. Krishna AK, Govil PK (2004) Heavy metal contamination of soil around Pali industrial area, Rajasthan, India. Environ Geol 47:38-44. https://doi.org/10.1007/s00254-004-1124-y 
36. Krupanidhi S, Sreekumar A, Sanjeevi CB (2008) Copper and biological health. Indian J Med Res 128(4):448-461

37. Kuri S, Billah MM, Rana SMM, Naim Z, Islam MM, Hasanuzzaman M (2014) Phytochemical and in vitro biological investigations of methanolic extracts of Enhydra fluctuans Lour. Asian Pac J Trop Biomed 4(4):299-305. https://doi.org/10.12980/APJTB.4.2014C677

38. Kushwaha A, Hans N, Kumar S, Rani R (2018) A critical review on speciation, mobilization and toxicity of lead in soil-microbe-plant system and bioremediation strategies. Ecotoxicol Environ Saf 147:1035-1045. https://doi.org/10.1016/j.ecoenv.2017.09.049

39. Lara MAM, Blazquez G, Trujillo MC, Perez A, Calero M (2014) New treatment of real electroplating wastewater containing heavy metal ions by adsorption onto olive stone. J Clean Prod 81:120-129. https://doi.org/10.1016/j.jclepro.2014.06.036

40. Li T, Xiong Z-T (2004) A novel response of wild-type duckweed (Lemna paucicostata Hegelm) to heavy metals. Environ Toxicol 19(2):95-102. https://doi.org/10.1002/tox.20000

41. Lokeshwari H, Chandrappa GT (2007) Effects of heavy metal contamination from anthropogenic sources on Dasarahalli tank, India. Lakes Reserv Res Manag 12(3):121-128.

https://doi.org/10.1111/j.1440-1770.2007.00337.x

42. Lokhande RS, Singare PU, Pimple DS (2011) Pollution in water of Kasardi River flowing along Tajola industrial area of Mumbai, India. World Environ 1(1):6-13. https://doi.org/10. 5923/j.env.20110101.02

43. Lytle CM, Lytle FW, Yang N, Qian JH, Hansen D, Zayed A, Terry N (1998) Reduction of $\mathrm{Cr}(\mathrm{VI})$ to $\mathrm{Cr}(\mathrm{III})$ by wetland plants: potential for in situ heavy metal detoxification. Environ Sci Technol 32(20):30873093. https://doi.org/10.1021/es980089x

44. Maldonado-Magaña A, Favela-Torres E, Rivera-Cabrera F, Volke-Sepulveda TL (2011) Lead bioaccumulation in Acacia farnesiana and its effect on lipid peroxidation and glutathione production. Plant Soil 339:377-389. https://doi.org/10.1007/s11104-010-0589-6

45. Maletić SP, Beljin JM, Rončević SD, Grgić MG, Dalmacija BD (2019) State of the art and future challenges for polycyclic aromatic hydrocarbons is sediments: sources, fate, bioavailability and remediation techniques. J Hazard Mater 365:467-482.

https://doi.org/10.1016/j.jhazmat.2018.11.020

46. Mant C, Costa S, Williams J, Tambourgi E (2007) Phytoremediation of chromium by model constructed wetland. Bioresour Technol 97(15):1767-1772.

https://doi.org/10.1016/j.biortech.2005.09.010

47. Miretzky P, Saralegui A, Fernandez Cirelli A (2004) Aquatic macrophytes potential for the simultaneous removal of heavy metals (Buenos Aires, Argentina). Chemosphere 57(8):997-1005. https://doi.org/10.1016/j.chemosphere.2004.07.024

48. Mishra VK, Tripathi BD (2008) Concurrent removal and accumulation of heavy metals by the three aquatic macrophytes. Bioresour Technol 99(15):7091-7097.

https://doi.org/10.1016/j.biortech.2008.01.002 
49. Mishra VK, Upadhyay AR, Pathak V, Tripathi BD (2008) Phytoremediation of Mercury and Arsenic from tropical opencast coalmine effluent through naturally occurring aquatic macrophytes. Water Air Soil Pollut 192:303-314. https://doi.org/10.1007/s11270-008-9657-4

50. Mishra VK, Tripathi BD, Kim KH (2009) Removal and accumulation of mercury by aquatic macrophytes from an open cast coal mine effluent. J Hazard Mater 172(2-3):749-754. https://doi.org/10.1016/j.jhazmat.2009.07.059

51. Mo SC, Choi DS, Robinson JW (1989) Uptake of mercury from aqueous solution by duckweed: the effect of pH, copper, and humic acid. J Environ Health 24(2):135-146. https://doi.org/10.1080/10934528909375470

52. Moya TA, van den Dobbelsteen A, Ottelé M, Bluyssen PM (2019) A review of green systems within the indoor environment. Indoor Built Environ 28(3):298-309.

http://dx.doi.org/10.1177/1420326X18783042

53. Mufarrege MM, Hadad HA, Maine MA (2010) Response of Pistia stratiotes to heavy metals (Cr, Ni, and Zn) and phosphorous. Arch Environ Contam Toxicol 58:53-61. https://doi.org/10.1007/s00244009-9350-7

54. Occupational Knowledge International (2021) Lead Batteries. http://www.okinternational.org/leadbatteries/background [downloaded on 11 June, 2021]

55. Olguín EJ, Sánchez-Galván G (2012) Heavy metal removal in phytofiltration and phycoremediation: the need to differentiate between bioadsorption and bioaccumulation. New Biotechnol 30(1):3-8. https://doi.org/10.1016/j.nbt.2012.05.020

56. Paiva BL, de Oliveira JG, Azevedo RA, Ribeiro DR, da Silva MG, Vitoria AP (2009) Ecophysiological responses of water hyacinth exposed to $\mathrm{Cr}^{3+}$ and $\mathrm{Cr}^{6+} \ldots$ Environ Exp Bot 65(2-3):403-409. https://doi.org/10.1016/j.envexpbot.2008.11.012

57. Parth V, Murthy NN, Saxena PR (2011) Assessment of heavy metal contamination in soil around hazardous waste disposal sites in Hyderabad city (India): natural and anthropogenic implications. J Environ Res Manage 2(2):27-34

58. Prasad MNV, Freitas H (2003) Metal hyperaccumulation in plants-Biodiversity prospecting for phytoremediation technology. Electron J Biotechnol 6(3):285-321

59. Pulford ID, Watson C, Mcgregor SD (2001) Uptake of chromium by trees: prospects for phytoremediation. Environ Geochem Health 23:307-311. https://doi.org/10.1023/A:1012243129773

60. Putra RS, Cahyana F, Novarita D (2015) Removal of lead and copper from contaminated water using EAPR system and uptake by Water Lettuce (Pistia Stratiotes L.). Procedia Chem 14:381-386. https://doi.org/10.1016/j.proche.2015.03.052

61. Qiao X, Shi G, Chen L, Tian X, Xu X (2013) Lead-induced oxidative damage in steriled seedlings of Nymphoides peltatum. Environ Sci Pollut Res 20:5047-5055. https://doi.org/10.1007/s11356-0131475-6

62. Rahman MT, Begum N, Alimuzzaman M, Khan MOF (2002) Analgesic activity of Enhydra fluctuans. Fitoterapia 73:707-709 
63. Rai LC, Gaur JP, Kumar HD (1981) Phycology and heavy metal pollution. Biol rev Camb Philos Soc 56(2):99-151. https://doi.org/10.1111/j.1469-185X.1981.tb00345.x

64. Raskin I, Ensley BD (2000) Phytoremediation of toxic metals: using plants to clean up the environment. John Wiley, New York

65. Rezania S, Taib SM, Din MFM, Dahalan FA, Kamyab H (2016) Comprehensive review on phytotechnology: Heavy metals removal by diverse aquatic plants species from wastewater. $\mathrm{J}$ Hazard Mater 318:587-599. https://doi.org/10.1016/j.jhazmat.2016.07.053

66. Sannigrahi S, Mazumdar UK, Pal D, Mishra SL, Maity S (2011) Flavonoids of Enhydra fluctuans exhibits analgesic and anti-inflammatory activity in different animal models. Pak J Pharm Sci 24(3):369-375

67. Sarwar N, Imran M, Shaheen MR, Ishaque W, Kamran MA, Matloob A, Hussain S (2017) Phytoremediation strategies for soils contaminated with heavy metals: Modifications and future perspectives. Chemosphere 171:710-721. https://doi.org/10.1016/j.chemosphere.2016.12.116

68. Seidal K (1976) Macrophytes and water purification. In: Tourbier J, Pierson RW (eds) biological control for water pollution. Pennsylvania University Press, Pennsylvania, pp 109-121

69. Shaheen R, Mitra N, Mahmud R (2006) Assessment of arsenic accumulation efficiency by selected naturally grown weeds. Int J Sustain Crop Prod 1(2):24-31

70. Shaheen R, Arefin MT, Mahmud R (2007) Phytoremediation of Boron contaminated soils by naturally grown weeds. J Soil Nat 1(1):01-06

71. Shanker AK, Ravichandran V, Pathmanabhan G (2005b) Phytoaccumulation of chromium by some multipurpose tree seedlings. Agrofor Syst 64:83-87. https://doi.org/10.1007/s10457-005-2477-2

72. Singh DB, Prasad G, Rupainwar DC (1996) Adsorption technique for the technique of $A s(V)$ rich effluents. Colloids Surf 111(1-3):49-56. https://doi.org/10.1016/0927-7757(95)03468-4

73. Sood A, Uniyal PL, Prasanna R, Ahluwalia AS (2012) Phytoremediation potential of aquatic macrophyte. Azolla AMBIO 41:122-137. https://doi.org/10.1007/s13280-011-0159-z

74. Srivastava J, Gupta A, Chandra H (2008) Managing water quality with aquatic macrophytes. Rev Environ Sci Biotechnol 7:255-266. https://doi.org/10.1007/s11157-008-9135-x

75. Sun YB, Zhou QX, Wang L, Liu WT (2009) Cadmium tolerance and accumulation characteristic of Bidens pilosa L. as a potential Cd-hyperaccumulator. J Hazard Mater 161(2-3):808-814. https://doi.org/10.1016/j.jhazmat.2008.04.030

76. Tangahu BV, Abdullah SRS, Basri H, Idris M, Anuar N, Mukhlisin M (2011) A review on heavy metals (As, $\mathrm{Pb}$, and $\mathrm{Hg}$ ) uptake by plants through phytoremediation. Int $\mathrm{J}$ Chem Eng 1-31. https://doi.org/10.1155/2011/939161

77. Terry N, Banuelos GS (2000) Phytoremediation of contaminated soil and water. Lewis Publisher, Boca Rotan

78. Verma R, Suthar S (2015) Lead and Cadmium removal from water using duckweed- Lemna gibba L.: Impact of pH and initial metal load. Alex Eng J 54(4):1297-1304. 
https://doi.org/10.1016/j.aej.2015.09.014

79. Wang WX, Dei RCH (2001) Effects of major nutrient additions on metal uptake in phytoplankton. Environ Pollut 111(2):233-240. https://doi.org/10.1016/S0269-7491(00)00071-3

80. Wolverton BC, McDonald RC (1976) Don't waste waterweeds. New Sci 71:318-320

81. Wolverton BC, McKown MM (1976) Water hyacinths for removal of phenols from polluted waters. Aquat Bot 2:191-201. https://doi.org/10.1016/0304-3770(76)90020-6

82. Zhang Y, Li C, Ji X, Yun C, Wang M, Luo X (2020) The knowledge domain and emerging trends in phytoremediation: a scientometric analysis with CiteSpace. Environ Sci Pollut Res 27:15515-15536. https://doi.org/10.1007/s11356-020-07646-2

\section{Supplementary Files}

This is a list of supplementary files associated with this preprint. Click to download.

- SupplementaryTableS.docx 